\title{
Effect of Aspergillus niger Fermented Soybean Meal Supplementation in Formulated Diets on Growth Performances in Juvenile Asian Seabass (Lates culcarifer Bloch)
}

\section{Worawut KOEDPRANG* and Uton CHAROENDAT}

Department of Fisheries Technology, Faculty of Science and Fisheries Technology, Rajamangala University of Technology Srivijaya, Trang Campus, Trang 92150, Thailand

('Corresponding author's e-mail: worawut2000@hotmail.com)

Received: 11 April 2018, Revised: 12 February 2019, Accepted: 13 March 2019

\begin{abstract}
The utilization of indigenous mold Aspergillus niger from aquaculture areas to improve the quality of soybean meal (SM) by fermentation and replacement in Asian seabass diet was studied on growth performances and feed utilization in juvenile Asian seabass, Lates calcalifer. Sinking diets with $40 \%$ of protein were formulated. The main sources of protein in the diets were from fish meal (FM). Low substitution levels of $4 \%$ of protein from SM, $10 \%$ of total protein, were used in diets D1 - D4 with replacement of fermented soybean meal (FSM) at 0, 25, 75, and 100\%, respectively, and high substitution levels of $8 \%$ of protein from SM, $20 \%$ of total protein, were used in diets D5 - D8 with replacement of FSM at $0,25,75$, and $100 \%$, respectively. Initial weight of juvenile Asian seabass was $12.83-12.90$ g. 10 fish were stocked in $100 \mathrm{~L}$ glass tanks with triplicate groups. Each diet was fed to apparent satiation twice daily for 10 weeks. The results presented that the final body weight (BW), specific growth rate (SGR), feed conversion ratio (FCR), protein efficiency ratio (PER), and feed capital showed significant difference $(P<0.05)$ while final total length $(\mathrm{TL})$, survival rate $(\mathrm{SR})$, carcass percentage, and hepatosomatic index (HSI) did not show significant difference $(P>0.05)$. The $4 \%$ of protein from SM was able to be replaced by $25-100 \%$ of FSM with increased growth performances and feed utilization, while feed cost (Thai baht $\mathrm{kg}^{-1}$ of fish) was reduced, respectively. The A. niger FSM is alternative protein source for growth, feed utilization improvement, and feed cost reduction of Asian seabass farmers.
\end{abstract}

Keyword: Fermented soybean meal, Indigenous Aspergillus niger, Juvenile Asian seabass

\section{Introduction}

Asian seabass, Lates calcalifer Bloch, 1970, is a brackish water fish species that is widely distributed in the Persian Gulf, throughout India, Southeast Asia, Northern Australia, Papua New Guinea, and the western Pacific. It is a significant culturally and economically important species in tropical Australasia, Asian countries bordering the Indian Ocean [1], and Thailand. The Asian seabass production of Thailand was 16,501 tons with the value of 2,029.96 million baths in 2014 [2]. The main cost of seabass production is feed, $50-70 \%$ of total production cost. The major source of protein in aquafeed is fish meal. The variability of landing of fish used to make fish meal has led to a decrease in fish meal production, while the price of the fish meal has increased due to high demand for aquafeed industries, causing the price of feed becoming more expensive [3]. Fish meal with plant protein ingredients is an alternative to reduce fish meal used and decrease feed price. Soybean meal is an ingredient widely used in aquafeed formulations. However, soybean meal contains a variety of antinutritional substances, protease inhibitors, lectins, phytic acid, saponins, phytoestrogens, antivitamins, and allergens [4]. There is a 
http://wjst.wu.ac.th

decrease of nutritional utilization of feed and growth performance in animals [5]. Therefore, usage of soybean meal is limited in aquafeeds, as Lee et al. replaced $20-40$ percent of fish meal protein by soybean meal in juvenile rockfish, Sebastes schlegeli, resulting in decrease in feed intake, feed efficiency (FE), protein efficiency ratio (PER), and growth rate [6]. Romarheim et al., Heikkinen et al., and Merrifield et al. reported that usage of soybean meal in rainbow trout, Oncorhynchus mykiss, resulted in reduced growth and morphological abnormality of the distal intestine, as well as changes in a microbial community in the intestine [7-9].

Antinutritional substances in feed material can be reduced by various methods: heating, a combination of heating and solvents [10], and infrared radiation [11]. Heating by autoclave for $15-30$ min reduced trypsin inhibitors in soybean meal, leading to them being under critical levels [12]. However, heating can destroy heat-labile factors; protease inhibitors, phytates, lectins, and antivitamins, whereas heat stable factors; saponins, non-starch polysaccharides, antigenic proteins, estrogens, and some phenolic compounds remain [5]. Francis et al. mentioned that, although heating can destroy heat-labile antinutritional factors, it also affects the nutritional quality of feed materials, such as a decrease in protein digestibility due to excessive heat denaturation and loss of availability of lysine [4].

Fermentation is a method can reduce antinutritional substances in soybean meal [4]. The bacteria consume sugar from the plant by cellulose and carbohydrate digestion for their energy and produce volatile fatty acids (VFAs), such as acetic acid, lactic acid, propionic acid, [13] etc. Lactic acid affected the reduction of antinutritional substances [14]. The study of Hong et al. found that soybean meal fermentation by mold Aspergillus oryzea destroyed trypsin inhibitors and increased the number of smallsize peptides $(<20 \mathrm{kDa})[15]$. A. niger is a kind of mold that has a similar attribute to A. oryzae. A. niger is a black-spored filamentous fungus. It can be found in soil, compost, and decaying plant material. It is able to grow in a wide temperature range of $6-47^{\circ} \mathrm{C}$, with optimum growth at $35-37{ }^{\circ} \mathrm{C}[16]$. The property of substance production of $A$. niger has been reported, such as citric acid, pectinase, amyloglucosidase [16], protease [17,18], cellulose and hemicellulases [19], lipase [20], phytase [21], tannase [22], etc. Moreover, A. niger is accepted as a safe organism for production of extracellular enzymes and citric acid for food industries and is considered Generally Recognized as Safe (GRAS) by the United States Food and Drug Administration. It has never been identified as being the primary cause of any disease in human. [16].

An indigenous microorganism in the aquaculture area in the Faculty of Science and Fisheries Technology, Rajamangala University of Technology Srivijaya, Trang campus, Thailand, was surveyed in order to its utilization for natural aquaculture, following the natural farming principles [23]. The theory of natural farming is producing high yields with minimal inputs, and utilizes local natural resources, including indigenous microorganisms [24]. The survey found several types of bacteria and mold, included A. niger [23]. The properties of A. niger were previously mentioned; soybean meal fermented by the indigenous $A$. niger in the formulated diet was estimated, in order to improve the growth and feed utilization of Asian seabass.

\section{Materials and methods}

Fermentation of soybean meal

Aspergillus niger was isolated from the aquaculture area in the Faculty of Science and Fisheries Technology, Trang campus. Fermentation of soybean meal (SM) was modified from the Yamamoto et al. [25] and Kim et al. [26] methods. A. niger hyphae were grown on PDA and used for A. niger starter production. The SMB was rehydrated with $30 \%\left(\mathrm{w} \mathrm{w}^{-1}\right)$ of water for $30 \mathrm{~min}$, put in a plastic bag, and sterilized for $15 \mathrm{~min}$. After cooling, A. niger hyphae was inoculated into SM and incubated at room temperature for about 10 - 15 days, until the hyphae grew to the bottom of the bag. Fermented soybean meal (FSM) was produced, plain SM was rehydrated to be the same as the starter produce method, $10 \%$ $\left(\mathrm{w} \mathrm{w}^{-1}\right)$ of starter was added, and it was mixed well and incubated at room temperature for $48 \mathrm{~h}$. The FSM was stocked in $-20{ }^{\circ} \mathrm{C}$ for proximate analysis [27] and diet production. 


\section{Diet production}

The isonitrogenous (40\%) and isolipidic (10\%) sinking diets were formulated (Table 1). Fish meal (FM) was used as the main protein source. $4 \%$ of protein from SM (10\% of total protein in diet) was used in diets D1 - D4 with replacement of FSM at $0,25,75$, and $100 \%$, respectively, and $8 \%$ of protein from SM ( $20 \%$ of total protein in diet) was used in diets D5 - D8 with replacement of FSM at $0,25,75$, and $100 \%$, respectively. The other ingredients of the diets are shown in Table 1. The diets were stocked in $-20^{\circ} \mathrm{C}$ for proximate analysis [27] and the experiment.

\section{Fish husbandry}

Juvenile Asian seabass were stocked in a $3 \mathrm{~m}^{3}$ tank with $15 \mathrm{ppt}$ of water and trained with the fed control diet (D1) twice daily to apparent satiation for 2 weeks. After acclimatization, the fish were starved for $24 \mathrm{~h} \mathrm{[28]} \mathrm{and} \mathrm{anesthetized} \mathrm{with} 50 \mathrm{ppm}$ clove oil. The body weight (BW) and the total length (TL) were measured individually. 10 uniform-sized fish (approximately $12 \mathrm{~g}$ body weight) were stocked in each of 30 glass tanks with $100 \mathrm{~L}$ of water volume and aeration. The fish were acclimatized to the experimental condition and fed control diet for a week. Each diet was fed to apparent satiation twice daily to 3 replicate tanks for 10 weeks [28].

\section{Data collections}

The measurement of final BW, TL, and survival rate (SR) were done at $10^{\text {th }}$ week individually. The amount of feed through the experiment was recorded for feed intake (FI), feed convention ratio (FCR), and protein efficiency ratio (PER) calculations. The edible portion and liver weights were determined for carcass percentage and hepatosomatic index (HSI) calculations.

Table 1 Composition (\%), proximate analysis, and cost of the experimental Asian Seabass diets.

\begin{tabular}{|c|c|c|c|c|c|c|c|c|}
\hline \multirow{2}{*}{ Ingredients (\%) } & \multicolumn{8}{|c|}{ Experimental diets } \\
\hline & D1 & D2 & D3 & D4 & D5 & D6 & D7 & D8 \\
\hline FM (64.73\% CP) & 55.62 & 55.62 & 55.62 & 55.62 & 49.44 & 49.44 & 49.44 & 49.44 \\
\hline SM (41.40 \% CP) & 9.66 & 7.25 & 2.41 & 0 & 19.33 & 14.50 & 4.83 & 0 \\
\hline $\operatorname{FSM}(37.31 \% \mathrm{CP})$ & 0 & 2.68 & 8.04 & 10.72 & 0 & 5.36 & 16.08 & 21.44 \\
\hline Rice Bran & 0 & 9.90 & 11.70 & 12.65 & 14.30 & 16.20 & 19.80 & 21.67 \\
\hline Cooked Rice Meal & 17.12 & 15.90 & 13.46 & 12.19 & 9.93 & 7.40 & 2.51 & 0 \\
\hline Palm Oil & 1.60 & 1.65 & 1.77 & 1.82 & 0 & 0.10 & 0.34 & 0.45 \\
\hline Vitamin Mix $^{\mathrm{a}}$ & 1 & 1 & 1 & 1 & 1 & 1 & 1 & 1 \\
\hline Mineral Mix ${ }^{\mathrm{b}}$ & 1 & 1 & 1 & 1 & 1 & 1 & 1 & 1 \\
\hline $\mathrm{CMC}$ & 5 & 5 & 5 & 5 & 5 & 5 & 5 & 5 \\
\hline \multicolumn{9}{|c|}{ Proximate composition (\% dry matter) } \\
\hline Protein & 41.60 & 41.31 & 41.02 & 41.48 & 41.09 & 41.16 & 41.07 & 41.01 \\
\hline Lipid & 10.73 & 10.35 & 10.29 & 10.42 & 10.40 & 10.39 & 10.35 & 10.40 \\
\hline Ash & 18.26 & 18.21 & 18.22 & 18.30 & 18.00 & 18.21 & 18.09 & 18.17 \\
\hline Moisture & 9.20 & 9.89 & 9.54 & 9.53 & 9.40 & 9.39 & 9.69 & 9.53 \\
\hline Energy $(\mathrm{MJ} / \mathrm{Kg})$ & 17.35 & 17.68 & 17.81 & 17.70 & 17.13 & 17.68 & 17.85 & 17.19 \\
\hline Diet Cost (baht $\mathrm{kg}^{-1}$ ) & 35.88 & 35.87 & 35.86 & 35.85 & 34.93 & 34.91 & 34.88 & 34.86 \\
\hline
\end{tabular}




\section{Statistical analysis}

The data were subjected to 1-way analysis of variance (ANOVA) and the difference between treatment means were multiple compared using Duncan's Multiple Range Test with significance predetermined at $P<0.05$. Data on proportion were arcsine transformed [29] prior to analysis. The SigmaStat program version 3.5 was used for data analysis.

\section{Results}

\section{Growth performances}

The growth performances of juvenile Asian seabass were determined at $10^{\text {th }}$ week. The final BW was $35.53-46.30 \mathrm{~g}$, the TL was $13.46-14.66 \mathrm{~cm}$, the specific growth rate (SGR) was $1.44-1.83 \%$ day $^{-}$ ${ }^{1}$, and the SR was $70-100 \%$. The BW and SGR in D2 - D4 were higher than D1 and there were significant differences $(P<0.05)$, whereas D5 - D8 were not significantly different $(P>0.05)$ from D1 (Table 2). The TL and SR did not show significant differences $(P>0.05)$ among the diet groups (Table 2). The results exhibited that FSM replacement up to $25-100 \%$ of $10 \%$ of protein from SM (D2 - D4) in juvenile Asian seabass diet caused increase in body weight and SGR when compared with control diet (D1).

\section{Feed utilization}

The FI of all groups was $48.59-50.93 \mathrm{~g} \mathrm{fish}^{-1}$ and there were no significant differences $(P>0.05)$, while the FCR were $1.53-2.15$ and the FCR of D2 - D4 were significantly decreased when compared with the other groups. The PER were $1.11-1.59$ and presented a significant positive correlation with the FSM used levels, and D2 - D4 were significantly different $(P>0.05)$ from D1 and D5 - D8 (Table 3). The carcass percentages were $44.32-48.25 \%$ and HSI were $1.90-2.30 \%$ (Table 3), and there were no significant differences among groups. The feed capitals were $54.73-76.74$ Thai baht per $\mathrm{kg}$ of fish (Table 3). D4 presented a significant lowest cost when compared with other diets $(P>0.05)$.

Table 2 Body weight and length, specific growth rate (SGR), and survival rate (SR) \pm SE of Asian seabass affected by proportion of Aspergillus niger fermented soybean meal in the diets at $10^{\text {th }}$ week.

\begin{tabular}{ccccccc}
\hline \multirow{2}{*}{$\begin{array}{c}\text { Diet } \\
\text { Groups* }\end{array}$} & $\begin{array}{c}\text { Initial weight } \\
(\mathbf{g})\end{array}$ & $\begin{array}{c}\text { Final weight } \\
(\mathbf{g})\end{array}$ & $\begin{array}{c}\text { Initial length } \\
\mathbf{( \mathbf { c m } )}\end{array}$ & $\begin{array}{c}\text { Final length } \\
(\mathbf{c m})\end{array}$ & $\begin{array}{c}\text { SGR } \\
\left(\% \mathbf{~ d a y}^{-\mathbf{1}}\right)\end{array}$ & $\begin{array}{c}\text { SR } \\
(\mathbf{\%})\end{array}$ \\
\hline D1 & $12.87 \pm 0.04 \mathrm{a}$ & $37.68 \pm 0.08 \mathrm{~b}$ & $10.21 \pm 0.05 \mathrm{a}$ & $14.08 \pm 0.38 \mathrm{a}$ & $1.53 \pm 0.01 \mathrm{~b}$ & $80 \pm 5 \mathrm{a}$ \\
D2 & $12.88 \pm 0.05 \mathrm{a}$ & $45.39 \pm 1.24 \mathrm{a}$ & $10.32 \pm 0.08 \mathrm{a}$ & $14.66 \pm 0.38 \mathrm{a}$ & $1.79 \pm 0.04 \mathrm{a}$ & $95 \pm 5 \mathrm{a}$ \\
D3 & $12.83 \pm 0.04 \mathrm{a}$ & $45.81 \pm 2.66 \mathrm{a}$ & $10.19 \pm 0.07 \mathrm{a}$ & $14.35 \pm 0.47 \mathrm{a}$ & $1.82 \pm 0.09 \mathrm{a}$ & $80 \pm 0 \mathrm{a}$ \\
D4 & $12.90 \pm 0.05 \mathrm{a}$ & $46.30 \pm 1.08 \mathrm{a}$ & $10.18 \pm 0.07 \mathrm{a}$ & $14.51 \pm 0.24 \mathrm{a}$ & $1.83 \pm 0.04 \mathrm{a}$ & $85 \pm 5 \mathrm{a}$ \\
D5 & $12.90 \pm 0.05 \mathrm{a}$ & $35.53 \pm 0.84 \mathrm{~b}$ & $10.17 \pm 0.06 \mathrm{a}$ & $13.46 \pm 0.48 \mathrm{a}$ & $1.44 \pm 0.03 \mathrm{~b}$ & $100 \mathrm{a}$ \\
D6 & $12.83 \pm 0.04 \mathrm{a}$ & $37.64 \pm 1.79 \mathrm{~b}$ & $10.23 \pm 0.07 \mathrm{a}$ & $14.02 \pm 0.45 \mathrm{a}$ & $1.54 \pm 0.07 \mathrm{~b}$ & $80 \pm 5.77 \mathrm{a}$ \\
D7 & $12.82 \pm 0.04 \mathrm{a}$ & $38.19 \pm 2.69 \mathrm{~b}$ & $10.18 \pm 0.04 \mathrm{a}$ & $13.60 \pm 0.40 \mathrm{a}$ & $1.55 \pm 0.11 \mathrm{~b}$ & $70 \pm 10 \mathrm{a}$ \\
D8 & $12.81 \pm 0.03 \mathrm{a}$ & $38.21 \pm 1.97 \mathrm{~b}$ & $10.21 \pm 0.06 \mathrm{a}$ & $13.76 \pm 0.46 \mathrm{a}$ & $1.56 \pm 0.07 \mathrm{a}$ & $85 \pm 5 \mathrm{a}$ \\
\hline
\end{tabular}

* D1 - D4 are diets with $10 \%$ of protein from soybean meal replaced by fermented soybean meal $0,25,75$, and $100 \%$, respectively. D5 - D8 are diets with $20 \%$ of protein from soybean meal replaced by fermented soybean meal $0,25,75$, and $100 \%$, respectively. Different alphabet in the same column indicates significant statistical difference $(P<0.05)$. 
http://wjst.wu.ac.th

Table 3 Feed intake (FI), feed conversion ratio (FCR), protein efficiency ratio (PER), carcass percentage, hepatosomatic index (HSI), and feed capital \pm SE of Asian seabass affected by proportion of Aspergillus niger fermented soybean meal in the diets at $10^{\text {th }}$ week.

\begin{tabular}{|c|c|c|c|c|c|c|}
\hline \multirow[b]{2}{*}{$\begin{array}{c}\text { Diet } \\
\text { Groups* }\end{array}$} & \multicolumn{6}{|c|}{ Performances } \\
\hline & $\begin{array}{c}\text { FI } \\
\left(\mathrm{g} \mathrm{fish}^{-1}\right)\end{array}$ & FCR & PER & Carcass & $\begin{array}{l}\text { HSI } \\
(\%)\end{array}$ & $\begin{array}{c}\text { Feed capital } \\
\left.\text { (Thai Baht } \mathrm{kg}^{-1}\right)\end{array}$ \\
\hline D1 & $51.77 \pm 0.19 a$ & $2.09 \pm 0.02 b$ & $1.15 \pm 0.01 b$ & $44.32 \pm 1.04 \mathrm{a}$ & $2.14 \pm 0.15 a$ & $74.96 \pm 0.63 c$ \\
\hline D2 & $54.16 \pm 0.84 a$ & $1.67 \pm 0.09 a$ & $1.45 \pm 0.08 \mathrm{a}$ & $47.77 \pm 0.27 \mathrm{a}$ & $2.30 \pm 0.62 \mathrm{a}$ & $59.95 \pm 3.31 \mathrm{ab}$ \\
\hline D3 & $53.39 \pm 0.65 a$ & $1.61 \pm 0.04 \mathrm{a}$ & $1.51 \pm 0.04 \mathrm{a}$ & $48.25 \pm 0.79 a$ & $1.90 \pm 0.33 \mathrm{a}$ & $57.82 \pm 1.42 \mathrm{ab}$ \\
\hline D4 & $50.93 \pm 1.22 \mathrm{a}$ & $1.53 \pm 0.12 \mathrm{a}$ & $1.59 \pm 0.12 \mathrm{a}$ & $47.75 \pm 0.39 a$ & $2.06 \pm 0.07 \mathrm{a}$ & $54.73 \pm 2.12 \mathrm{a}$ \\
\hline D5 & $48.59 \pm 1.69 \mathrm{a}$ & $2.15 \pm 0.05 b$ & $1.13 \pm 0.02 b$ & $48.13 \pm 1.51 \mathrm{a}$ & $2.03 \pm 0.29 a$ & $75.06 \pm 1.58 \mathrm{c}$ \\
\hline D6 & $54.12 \pm 1.33 \mathrm{a}$ & $2.20 \pm 0.14 b$ & $1.11 \pm 0.07 b$ & $45.90 \pm 0.85 a$ & $2.22 \pm 0.18 \mathrm{a}$ & $76.74 \pm 2.76 c$ \\
\hline D7 & $53.72 \pm 1.62 \mathrm{a}$ & $2.14 \pm 0.17 b$ & $1.14 \pm 0.0 \mathrm{~b}$ & $45.44 \pm 1.16 \mathrm{a}$ & $2.17 \pm 0.06 \mathrm{a}$ & $74.70 \pm 2.96 c$ \\
\hline D8 & $51.43 \pm 1.06 \mathrm{a}$ & $2.04 \pm 0.15 b$ & $1.21 \pm 0.09 \mathrm{~b}$ & $46.51 \pm 0.68 \mathrm{a}$ & $2.15 \pm 0.18 \mathrm{a}$ & $70.94 \pm 3.26 \mathrm{bc}$ \\
\hline
\end{tabular}

* D1 - D4 are diets with $10 \%$ of protein from soybean meal replaced by fermented soybean meal $0,25,75$, and 100 $\%$, respectively. D5 - D8 are diets with $20 \%$ of protein from soybean meal replaced by fermented soybean meal 0 , 25,75 , and $100 \%$, respectively. Different alphabet in the same column indicates significant statistical difference $(P<$ $0.05)$.

\section{Discussion}

$4 \%$ of protein from SM (10\% of total protein in diet) replaced by $25-100 \%$ of protein from Aspergillus niger FSM presented significant improvement $(P<0.05)$ of $\mathrm{BW}$, SGR, FCR, and PER of juvenile Asian seabass, while there was no effect on SR, carcass percentage, and HSI in this study. Cruz et al. [18] explained that the utilization of bacteria for feedstuff fermentation in appropriate conditions resulted in the reduction of antinutritional substances, and improved palatability as well as feed digest efficiency. During the fermentation process, bacteria produce various substances; acetic acid, lactic acid, propionic acid [14], etc. Lactic acid was able to destroy the antinutritional substances in soybean meal [14]. Likewise, the A. oryzea fermentation of SM reduced trypsin inhibitors and increased the number of small-size peptides, leading to an improvement of feed utilization [15]. The results of FM replacements by Bacillus spp. FSM in rainbow trout, Oncorhynchus mykiss [25], and red sea bream, Pagrus major [30], and utilization of $A$. oryzea FSM and A. oryzea directly mixed feed in parrotfish, Oplegnathus fasciatus [26] and olive flounder, Paralichthys olivaceus [31], showed higher growth rate and feed utilization than the control, while the survival rates were increased. Therefore, A. niger might have similar potential in SM fermentation, since it can yield functional substances; protease [15-17], cellulose and hemicellulases [19], lipase [20], phytase [21] and tannase [22], etc., during the process.

On the other hand, diets containing $8 \%$ of protein from SM (20\% of total protein in diet); D5 and $25-100 \%$ protein from FSM replaced diets (D6 - D8) in this study did not show significantly improved growth performances or feed utilization $(P>0.05)$ in juvenile Asian seabass; however, there was a trend for improvement. There might be a limited effect of soybean meal utilization in seabass. Tantikitti et al. reported that the replacement of FM by SM in Asian seabass should not exceed $10 \%$ without effect on growth performance, while over this resulted in growth rate suppression [32]. Similarly, tests in other carnivorous marine fish such as pompano, Trachinotus ovatus [33], and orange-spotted grouper, Epinephelus coioides [34] showed that up to $10 \%$ FM could be replaced by FSM without negative effects. Likewise, high levels of SM replacement affected performances in several fish species; decrease of feed efficiency (FE), PER, and growth rate in juvenile rockfish, Sebastes schlegeli [6], silver perch, Bidyanus bidyanus [35], and rainbow trout [7,8], while morphological abnormalities and bacterial community change of intestine were found in rainbow trout [8,9]. Drew et al. explained the reason of adverse growth performances with increased SM levels in the diet; SM is deficient in some essential amino acids (EAAs), methionine and lysine, which are important for fish growth [35]. Additionally, 
http://wjst.wu.ac.th

Azam and Lee reported that FSM was able to replace up to $40 \%$ of FM protein in juvenile black sea bream, Acanthopagrus schlegeli, with supplementation of methionine, lysine, and taurine, without a negative effect on growth performance [36] Yang et al. demonstrated that the supplementation of methionine and lysine into $60 \%$ of FSM replaced diet resulted in improved silver perch, Bidyanus, growth performance, while weight gain, FE, and PER declined in groups of fish fed higher levels of dietary FSM [37]. However, Martínez-Llorens et al. indicated that bigger fish seem to have higher tolerance to plant protein levels in diets than smaller fish [38], as the result of the FM being replaced by up to $40 \%$ of FSM did not affect growth rate, FI, FE, PER, or survival rate of grower rockfish [6]. Moreover, the various abilities of plant protein utilization depends on different tolerance limits to antinutritional factors (ANFs) in plant proteins, which varies among species of fish [4]. The ability in the utilization of FSM as FM substitute in juvenile rockfish is lower than the ability of juvenile black sea bream under similar experimental circumstances [6].

\section{Conclusions}

The results of this study can conclude that the $10 \%$ of total protein from SM protein in juvenile Asian seabass diet was able to substituted $25-100 \%$ of Aspergillus niger FSM protein with effect on increase in BW, SGR, PER, and decrease in FCR, without adverse effects on SR, FI, carcass percentage, or HSI. Although it was attempted to increase the inclusion levels of SM protein up to $20 \%$ of total protein in diet, including replacement of FSM protein in the diets, this did not improve the performances. Furthermore, when calculated, the feed capital per $\mathrm{kg}_{\text {fish }}{ }^{-1}$ from the FCR demonstrated that replacement of $10 \%$ of SM protein by $25-100 \%$ of FSM protein (D2 - D4) yielded almost $30 \%$ lower cost than the others (D1 and D5 - D8), while the lowest was $100 \%$ replacement (D4). This may suggest that $10 \%$ of SM protein can replace $100 \%$ of FSM protein in juvenile Asian seabass diet. Further study is needed to determine the available SM or FSM protein inclusion levels and EAAs addition in grower Asian seabass diet in order to reduce FM utilization, as well as improve product capital economization.

The indigenous $A$. niger from the aquaculture area of the Faculty of Science and Fisheries Technology, Rajamangala University of Technology Srivijaya, is an effective fungus for quality improvement of SM. A. niger FSM is an alternative protein source for growth and feed utilization improvement of Asian seabass. In addition, Asian seabass culturists can reduce feed cost by using FSM mixed feed and raise satisfactory income.

\section{Acknowledgements}

We thank all of our supporters. This study was financially supported by the Rajamangala University of Technology Srivijaya, Thailand, and the experimental facilities were supported by the Faculty of Science and Technology, Trang campus. Also, thanks to the technicians and students for their assistance.

\section{References}

[1] R Pethiyagoda and AC Gill. Taxonomy and Distribution of Indo-Pacific Lates. In: RJ Dean (Ed.). Biology and Culture of Asian Seabass Lates calcarifer. CRC Press, New York, 2014, p. 1-15.

[2] Department of Fisheries. Fisheries Statistics of Thailand 2014 (in Thai). Information and Communication Technology Center, Department of Fisheries, Ministry of Agriculture and Cooperatives, Thailand, 2014, p. 24-41.

[3] RW Hardy. Utilization of plant proteins in fish diets: Effects of global demand and supplies of fishmeal. Aquacult. Res. 2010; 41, 770-6.

[4] G Francis, HPS Makkar and K Becker. Antinutritional factors present in plant-derived alternate fish feed ingredients and their effects in fish. Aquaculture 2001; 199, 197-227.

[5] Y Tadele. Important anti-nutritional substances and inherent toxicants of feeds. Food Sci.Qual. Manag. 2015; 36, 40-7. 
http://wjst.wu.ac.th

[6] SM Lee, HM Azarm and KH Chang. Effects of dietary inclusion of fermented soybean meal on growth, body composition, antioxidant enzyme activity and disease resistance of rockfish (Sebastes schlegeli). Aquaculture 2016; 459, 110-6.

[7] $\mathrm{OH}$ Romarheim, A Skrede, Y Gao, A Krogdahl, V Denstadli, E Lilleeng and T Storebakken. Comparison of white flakes and toasted soybean meal partly replacing fish meal as protein source in extruded feed for rainbow trout (Oncorhynchus mykiss). Aquaculture. 2008; 256, 354-64.

[8] J Heikkinen, J Vielma, O Kemiläinen, M Tiirola, P Eskelinen, T Kiuru, D Naiva-Paldanius and A von Wright. Effects of soybean meal based diet on growth performance, gut histopathology, and intestinal microbiota of juvenile rainbow trout (Oncorhynchus mykiss). Aquaculture. 2006; 261, 259-68.

[9] DL Merrifield, A Dimitroglou, G Bradley, RTM Baker and SJ Davies. Soybean meal alters autchthonous microbial populations, microvilli morphology and compromises intestinal enterocyte integrity of rainbow trout, Oncorhynchus mykiss (Walbaum). J. Fish Diseases 2009; 32, 755-66.

[10] FT Barrows, DAJ Stone and RW Hardy. The effects of extrusion conditions on the nutritional value of soybean meal for rainbow trout (Oncorhynchus mykiss). Aquaculture 2007; 265, 244-52.

[11] EF Gomes, P Rema and SJ Kaushik. Replacement of fish meal by plant proteins in the diet of rainbow trout (Oncorhynchus mykiss): digestibility and growth performance. Aquaculture 1995; 13, 177-86.

[12] G Norton. Proteinase Inhibitors. In: FJP D’Mello, CM Duffus and JH Duffus (Eds.). Toxic Substances in Crop Plants. The Royal Society of Chemistry, Thomas Graham House, Science Park, Cambridge CB4 4WF, Cambridge, 1991, p. 68-106.

[13] S Chiba, H Chiba and M Yagi. A Guide for Silage Making and Utilization in the Tropical Regions. Japan Livestock Technology Association, Japan, 2005, p. 29.

[14] Y Cruz, C Kijora, E Wedler, J Danier and C Schulz. Fermentation properties and nutritional quality of selected aquatic macrophytes as alternative fish feed in rural areas of the Neotropics. Livestock Res. Rural Develop. 2011; 23, 239.

[15] KJ Hong, CH Lee and SW Kim. Aspergillus oryzae GB-107 fermentation improves nutritional quality of food soybeans and feed soybean meals. J. Med. Food. 2004; 7, 430-5.

[16] E Schuster, N Dunn-Coleman and JC Frisvad. On the safety of Aspergillus niger. Appl. Microbiol. Biotechnol. 2002; 59, 426-35.

[17] FC Yang and IH Lin. Production of acid protease using thin stillage from a rice spirit distillery by Aspergillus niger. Enzyme Microb. Technol. 1998; 23, 397-402.

[18] S.Couri, SC Terzi, GS Pinto, SP Freitas and ACA Costa. Hydrolytic enzyme production in solidstate fermentation by Aspergillus niger 3T5B8. Process. Biochem. 2000; 36, 255-61.

[19] SW Kang, YS Park, JS Lee, SI Hong and SW Kim. Production of cellulases and hemicellulases by Aspergillus niger KK2 from lignocellulosic biomass. Bioresour. Technol. 2004; 91, 153-6.

[20] ND Mahadik, US Puntambekar, KB Bastawde, JM Khire and DV Gokhale. Production of acidic lipase by Aspergillus niger in solid state fermentation. Process. Biochem. 2002; 38, 715-1.

[21] A Casey and G Walsh. Purification and characterization of extracellular phytase from Aspergillus niger ATTCC 9142. Bioresour. Technol. 2003; 86, 183-8.

[22] CN Aguilar, C Augur, E Favela-Torres and G Viniegra-González. Production of tannase by Aspergillus niger Aa-20. In submerged and solid-state fermentation: Influence of glucose and tannic acid. J. Ind. Microbiol. Biotechnol. 2001; 26, 296-302.

[23] W Koedprang and $\mathrm{C}$ Chalad. Indigenous microorganism in aquaculture area based on natural farming principles, Case study: Freshwater aquaculture farm, Faculty of Science and Fisheries Technology, Rajamangala University of Technology Srivijaya, Trang campus (in Thai). Rajamangala Univ. Tech. Tawan-ok Res. J. 2015; 8, 52-7.

[24] R Reddy. Cho's Global Natural Farming. South Asian Rural Reconstruction Association, Bangalore, India, 2011, p. 1-4.

[25] T Yamamoto, Y Iwashita, H Matsunari, T Sugita, H Furuita, A Akimoto, K Okamatsu and N Suzuki. Influence of fermentation conditions for soybean meal in a non-fish meal diet on the growth 
http://wjst.wu.ac.th

performance and physiological condition of rainbow trout Oncorhynchus mykiss. Aquaculture 2010; 309, 173-80.

[26] SS Kim, GB Galaz, MA Pham, JW Jang, DH Oh, IK Yeo and KJ Lee. Effects of dietary supplementation of meju, fermented soybean meal, and Aspergillus oryzae for juvenile parrot fish (Oplegnathus fasciatus). Asian Australian J. Anim. Sci. 2009; 22, 849-56.

[27] JM Padmore. Animal Feed. In: AOAC (Ed). Official Method of Analysis. Vol I. $15^{\text {th }}$ ed. Washington DC, USA, 1990, p. 69-90.

[28] XF Liang, L Hu, YC Dong, XF Wu, YC Qin, YH Zheng, DD Shi, M Xue and XF Liang. Substitution of fish meal by fermented soybean meal affects the growth performance and flesh quality of Japanese seabass (Lateolabrax japonicus). Anim. Feed Sci. Tech. 2017; 229, 1-12.

[29] JH McDonald. Handbook of Biological Statistics. $3^{\text {rd }}$ ed. Sparky House Publishing, Baltimore Maryland, 2014, p. 140-4.

[30] MA Kader, S Koshio, M Ishikawa, S Yokoyama, M Bulbul, Y Honda, RE Mamauag and A Laining. Growth, nutrient utilization, oxidative condition, and element composition of juvenile red sea bream Pagrus major fed with fermented soybean meal and scallop byproduct blend as fishmeal replacement. Fish. Sci. 2011; 77, 119-28.

[31] SS Kim, MA Pham, KW Kim, MH Son and KJ Lee. Effects of microbial fermentation of soybean on growth performances, phosphorous availability, and antioxidant activity in diets for juvenile olive flounder (Paralichthys olivaceus). Food Sci. Biotechnol. 2010; 19, 1605-10.

[32] C Tantikitti, W Sangpong and S Chiavareesajja. Effects of defatted soybean protein levels on growth performance and nitrogen and phosphorus excretion in Asian seabass (Lates calcarifer). Aquaculture 2005; 248, 41-50.

[33] H Lin, X Chen, S Chen, L Zhuojia, Z Huang, J Niu, K Wu and X Lu. Replacement of fish meal with fermented soybean meal in practical diets for pompano Trachinotus ovatus. Aquacult. Res. 2013; 44, 151-6.

[34] Z Luo, YJ Liu, KS Mai, LX Tian, DH Liu and XY Tan. Partial replacement of fish meal by soybean protein in diets for grouper Epinephelus coioides juveniles. J. Fish. China. 2004; 28, 175-81.

[35] MD Drew, TL Borgeson and DL Thiessen. A review of processing of feed ingredients to enhance diet digestibility in finfish. Anim. Feed Sci. Technol. 2007; 138, 118-36.

[36] HM Azarm and SM Lee. Effects of partial substitution of dietary fish meal by fermented soybean meal on growth performance, amino acid and biochemical parameters of juvenile black seabream Acanthopagrus schlegeli. Aquacult. Res. 2014; 45, 994-1003.

[37] SD Yang,TS Lin, FG Liu and CH Liou. Dietary Effects of Fermented Soybean Meal on Growth Performance, Body Composition and Hematological Characteristics of Silver Perch (Bidyanus). J. Taiwan Fish. Res. 2009; 17, 53-63.

[38] S Martínez-Llorens, AV Monino, AV Vidal, VJM Salvador, MP Torres and MJ Cerda. Soybean meal as a protein source in gilthead sea bream (Sparus aurata L.) diets: effects on growth and nutrient utilization. Aquacult. Res. 2007; 38, 82-90. 